\title{
Nonlinear Viscoelasticity of Polymer Concentrates
}

\author{
by \\ Kunihiro OsakI \\ Institute for Chemical Research, Kyoto University \\ $U j i, K$ yoto 611
}

\begin{abstract}
A brief account is given for the development of studies in nonlinear viscoelasticity of polymer melts and concentrated solutions. The first stage of rapid progress starting around 1950 was led by the discovery of the normal stress effect. In this period, the rheological properties in steady shear flow were extensively studied and the concept of entanglement network was introduced as the origin of stress in polymeric liquids. The second stage which was partly induced by the development of rheological apparatuses in steady shear, was concerned with the nonsteady as well as nonlinear stress-strain relations. About the middle of 1970 s, the strain-dependent constitutive equation was recognized as an appropriate equation to describe the stress for a wide group of flow histories. At the third stage of progress the tube model theory of Doi and Edwards was published in 1978 and it has been proved capable of describing most of the nonlinear viscoelastic behavior so far investigated. In the present paper a special emphasis is put on the birefringence induced by the strain. This phenomenon, if studied in appropriate nonsteady flows, may well give a clue to prove the molecular motion assumed in the tube model theory.
\end{abstract}

\section{高分子濃厚系の非線型粘弾性}

尾崎邦宏 ${ }^{*}$

（原稿受理：1983年10月 8 日）

\section{1. 序}

論

線状高分子の濃厚溶液や溶融体（併せて濃厚系と呼ぼう）の非 線型粘弾性举動については，1970年代の半ばに現象論的な構成方 程式の目途がついたのに続き，1978年に提出されたDoi-Edwards 理論 ${ }^{1}$ が相当に優秀であることが判明して，急激に進展した．非 線型粘弾性の研究が一つの区切りに達したと考学られるので, 今 までの研究経過をたどり，得られた結果をまとめて見よう。

高分子濃厚系のレオロジーの特徴は, 粘弾性（緩和性）と非線 型性である. 線型粘弾性 ${ }^{2)}$ はこの前者だけを対象とするものであ

\footnotetext{
* 京都大学化学研究所 $\mp 611$ 宇治市五ヶ庄
}

って，非線型性が問題にならないような微小な変形に対するレォ ロジーである.これは非線型粘弾性を研究する際の基礎となるも のであるが，ここでは述べない，本論文と対照して読むには，升 田の総説3)が適当であろ5。本論文では, 非線型粘弾性の研究に ついて述べる. 比較的早期の研究については既にまとまった解説 もあるので, 個々の研究について原典を引用することはなるべく 行わない。

\section{2. 定常ずり流動のレオロジー}

$2 \cdot 1$ 定常ずり流動と応力成分

丁度, 粘弾性が主に線型の範囲で研究されたよ5に, 初期に拉 
いては，非線型性は主に定常ずり流動について研究された．最初 に注目された非線型現象は, 粘度クがずり速度 $\dot{\gamma}$ の增加とともに 減少することである. これは高分子濃厚系のみならず, 粒子の分 散系に执いて広く認められる現象である. 高分子濃厚系の定常流 応力が粘性的なものだけでなく, 弾性的な成分を含み, 高分子の 線状構造とかかわっていることが強く認識されるようになったの

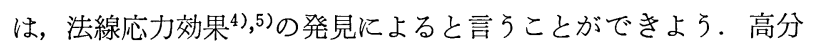
子液体に棒を突っ込んで回転させると, 液体は棒に沿ってはい上 がる.これは流線方向に余分な張力（法線応力）が発生し，その 合力が内向きの圧力になっているためであることは, Weissenberg によって指摘された. Weissenberg は更にこの現象がゴムの大変 形の際に見られる挙動と類似していることを示した. 法線応力効 果は, 高分子のような線状構造の物質，あるいは細長い粒子を含 む系だけに見られる現象である.

ここで定常ずり流動と，関連した応力成分を定義して扣こう． 正規直交系 $x_{1} x_{2} x_{3}$ に扮いて, 流れの速度を

$$
v_{1}=\dot{\gamma} x_{2}, \quad v_{2}=v_{3}=0
$$

とする.ずり速度 $\dot{゙} か ゙$ 時間に関係なく一定ならば，これは定常ず り流動である. このときの応力は, 変形の対称性から次の形にな ることがわかる。

$$
\sigma=\left(\begin{array}{ccc}
\sigma_{11} & \sigma_{12} & 0 \\
\sigma_{21} & \sigma_{22} & 0 \\
0 & 0 & \sigma_{33}
\end{array}\right), \quad \sigma_{12}=\sigma_{21}
$$

非圧縮性物質では，応力に等方的な圧力を付加しても変形状態は 変化しない，したがって，変形だけで決定される独立な量は 3 箇 である.

$$
\begin{array}{ll}
\sigma(\dot{\gamma}) \equiv \sigma_{12}=\sigma_{21} \equiv \dot{\gamma} \eta(\dot{\gamma}) & \text { (ずり応力) } \\
\nu_{1}(\dot{\gamma}) \equiv \sigma_{11}-\sigma_{22} \equiv \dot{\gamma}^{2} \theta(\dot{\gamma}) \quad \text { (第一法線応力差) } \\
\nu_{2}(\dot{\gamma}) \equiv \sigma_{22}-\sigma_{33} \equiv \dot{\gamma}^{2} \beta(\dot{\gamma}) \quad \text { (第二法線応力差) }
\end{array}
$$

の三つを，定常ずり流動の応力を表す量とするのが慣例である. 最右辺のよ 5 に関数 $\eta, \theta, \beta$ を定義する. 流動の対称性より，こ れらの量は $\dot{\gamma}$ の偶関数である. 二つの法線応力差 $\nu_{1}$ と $\nu_{2}$ を分 離測定することは，長期間にわたってレオロジ一の主要課題の一 つであり，このためにワイセンベルグレオゴニオイメータを始めと して, 数多くの測定装置が開発された ${ }^{6)}$. 回転棒に巻き上がるこ

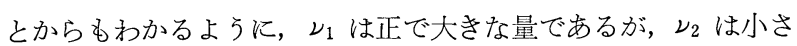
く，その評価は困難を極めた．よ5やく1970年頃に， $\nu_{2}$ は負であ り，その大きさは $\nu_{1}$ より 1 杵小さいことが明らかにされた7). 法 線応力効果を示す液体では, 器壁に穴をあけて圧力を測定すると 系統的な誤差が生じるが ${ }^{8)}$, その誤差の大きさは $\nu_{2}$ と同程度のこ とが多く, この事実が法線応力効果の初期の研究の混乱の一因と なったのである， レ2は測定に多くの努力を要した割には，その意 味合いがはっきり知られて抢らず，流動の解析の際にも $\nu_{2}$ の効 果は無視されることが多い.

定常ずり流動の応力に関して得られた結果の主要なるのを,

$2 \cdot 2$ および $2 \cdot 3$ 亿括いてまとめてみる.

\section{$2 \cdot 2$ 弾性体との対応および流動複屈折}

高分子濃厚系の定常流に括ける応力状態が，大変形下のゴムの ものに似ていることは, 法線応力効果の発見時に既に認められて いた. Philippoff $ら^{9)}$ および小高ら ${ }^{10)}$ は, 定常流応力の特性を記
述するために，この考光方を有効に用いた．ゴムのような弾性体 に大きさとのずりひずみを加えた場合, ずり応力执よび第一法線 応力差は $\sigma=G_{s} \gamma, \nu_{1}=G_{s} \gamma^{2}$ で与えられる. ここで, $G_{s}$ はずり弾 性率である.いま, 流動中の液体の応力が，仮想的な弾性体（弾 性率 $G_{l}$ ) に内部ひずみ $\gamma_{l}$ が生じたことに起因するものだと考觉 て，次のょうに書いてみる.

$$
\sigma=G_{l} \gamma_{l}, \nu_{1}=G_{l} \gamma_{l}{ }^{2}
$$

ずり速度 $\dot{\gamma}$ と内部ひずみ $\gamma_{l}$ を結びつけるものとして,

$$
\tau_{l}=\gamma_{l} / \dot{\gamma}
$$

を定義することができる．

$\sigma$ と $\nu_{1}$ の測定值から， $G_{l}, \gamma_{l}, \tau_{l}$ 等を求めることができる. $G_{l}$ の測定例11を Fig. 1 飞示す. 分子量分布の狭い線状高分子の 濃厚系に括いては， $G_{l}$ はあまり $\gamma_{l}$ (あるいは $\dot{\gamma}$ ) に依存せず, 仮想的な弾性体は近似的にフック弾性体とみなすことができる. $\eta や \theta$ け の增加に従って急激に減少する。この減少は主に緩和 時間 $\tau_{l}$ の非線型性に由来する.内部ひずみ $\gamma_{l}$ は Barus 効果や定 常流停止後のひずみの弾性的回復等と相関を持ち ${ }^{4), 5)}$, 高分子材 料の流動時の弾性効果を表す量として, 現在でもしばしば利用さ れる.

高分子濃厚系とゴム状弾性体の対応関係は, 更に応力に伴 万光 学的な異方性についても成立する。弾性体を変形させると, 応力 が発生するとともに, 屈折率にも異方性が生じて, 複屈折を示す ようになる. このとき, 応力の主軸方向と光学的な主軸の方向は 一致し, 応力の主值の差と屈折率の主值の差は比例する（光弾性 則 ${ }^{12)}$. ずり変形を受けている物質の $x_{3}$ 軸に垂直な応力成分 $\sigma_{11}$, $\sigma_{12}=\sigma_{21}, \sigma_{22}$ について考光る (Fig. 2). 応力主軸を $x_{1}, x_{\text {II }}$ とし て $x_{1}$ 軸と $x_{1}$ 軸の間の角度を $\chi$ とすると, 応力の主値の差 $\Delta \sigma \equiv$

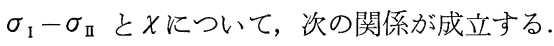

$$
\Delta \sigma=\left(\nu_{1}^{2}+4 \sigma^{2}\right)^{1 / 2}
$$

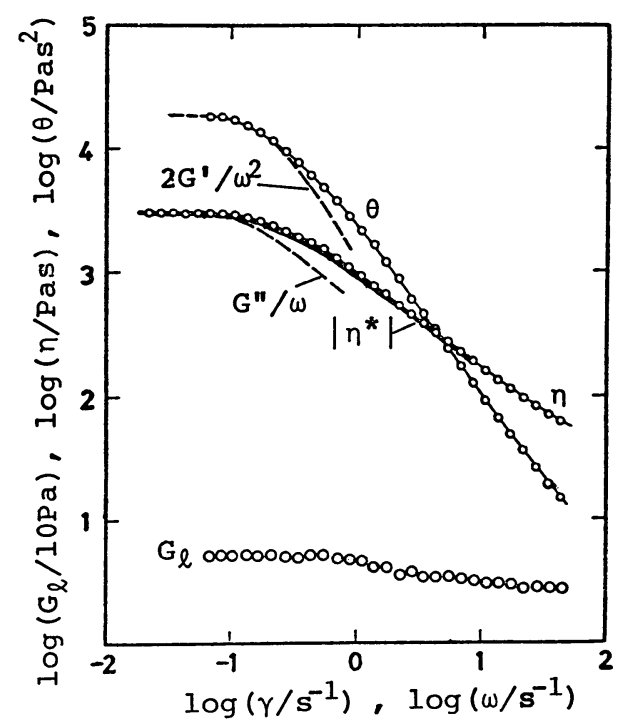

Fig. 1 Quantities characterizing steady shear flow of $10 \%$ solution of polystyrene (molecular weight $1.02 \times$ $10^{6}$ ) in chlorinated biphenyl at $30^{\circ} \mathrm{C}$. Thick line represents $\left|\eta^{*}\right|$ and dashed lines represent $2 G^{\prime} / \omega^{2}$ and $G^{\prime \prime} / \omega .^{11}$ 

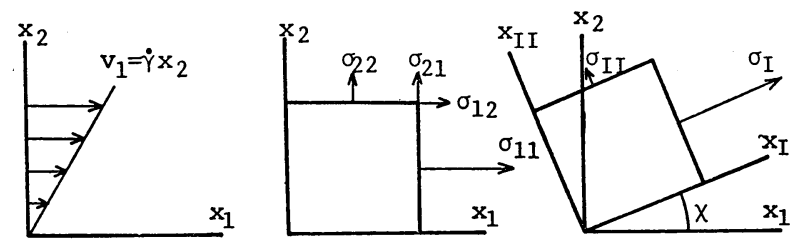

Fig. 2 Velocity profile in shear flow (left), stress components parallel to $x_{1} x_{2}$ plane (middle), and stress components in principal directions $x_{\mathrm{I}}$ and $x_{\text {II }}$ (right).

$$
2 \cot 2 \chi=\nu_{1} / \sigma
$$

光弾性則により，次の関係が得られる.

$$
\Delta n=C \Delta \sigma
$$

ただし， $\Delta n$ はそれぞれ $x_{1}$ 抢よび $x_{\mathrm{II}}$ 方向に偏った $x_{3}$ 軸方向の 光に対する屈折率の差であり， $C$ は光弹性係数と呼ばれる物質定 数である. 式(5)を $\nu_{1}, \sigma$ について解くと,

$$
\begin{aligned}
& 2 \sigma=\Delta \sigma \sin 2 \chi=\Delta n \sin 2 \chi / C \\
& \nu_{1}=\Delta \sigma \cos 2 \chi=\Delta n \cos 2 \chi / C
\end{aligned}
$$

が得られる.これは力学的な量 $\sigma, \nu_{1}$ と光学的に測定される量 $\Delta n, \chi$ の間の関係式と見なすことができる.

さて, 定常流下に扔ける高分子濃厚系について, 応力のみなら ず光学的異方性も，仮想的な弾性体のひずみによって生じると考 えると, 式(6)が成立すると期待される，この予想は Philippoff $ら^{9)}$, Janeschitz-Kriegl ら ${ }^{13), 14)}$ によって実験的に証明され，係数 $C$ が高分子の濃度や分子量に殆ど依存しないことなどが確かめら れた.この結果も仮想的な弾性体の考方方を支持するものであっ た.

\section{$2 \cdot 3$ 定常流応力之動的粘弾性の対応}

定常ずり流動に掓る応力のる5一つの重要な研究方法は, こ れを線型の動的粘弾性と関係づけよとするものであった，定常 ずり流動の際の㐫力と, 複素弾性率 $G^{*}(\omega)=G^{\prime}(\omega)+\mathrm{i} G^{\prime \prime}(\omega)$ の 間には,

$$
\begin{aligned}
& \lim _{\dot{\gamma} \rightarrow 0} \sigma / \dot{\gamma}=\lim _{\omega \rightarrow 0} G^{\prime \prime} / \omega \\
& \lim _{\dot{\gamma} \rightarrow 0} \nu_{1} / \dot{\gamma}^{2}=2 \lim _{\omega \rightarrow 0} G^{\prime} / \omega^{2}
\end{aligned}
$$

の関係が成立する，第一式は線型粘弾性の関係式に過ぎない，第 二式はde Witt ${ }^{15)}$ とって最初に見いだされ，その後非線型粘 弾性の現象理論によって, 一般的に成立することが証明された ${ }^{16)}$. 式(7)の成立を示す例を Fig. 1 の破線で示す。この関係によって, ずり速度の小さいときの $\sigma$ 执よび $\nu_{1}$ は, 線型粘弾性量で表すこ とができる. 例えば, 前述の内部ひずみ $\gamma_{l}$ は, 定常流からのク リープ回復量の 2 倍であり, 弾性率 $G_{l}$ は定常コンプライアンス ${ }^{3)}$ $J_{c}^{0}$ の逆数の $1 / 2$ である.

ずり速度 $\dot{゙}$ が增加していくと，ク抢よび $\theta$ は減少し始めるが, その減少し始める $\dot{\gamma}$ の值と, $2 G^{\prime} / \omega^{2}$ 扣よび $G^{\prime \prime} / \omega$ が減少し始め る $\omega$ の值は, 近似的に等しい(Fig. 1参照).この事実は, ク拈よ び $\theta$ の非線型性が, 線型粘弾性の最大緩和時間 $\tau_{1}{ }^{0}$ 之密接に関係 しており， $\dot{\gamma} \simeq\left(\tau_{1}^{0}\right)^{-1}$ のあたりで始めて非線型性が現れることを 示している.この関係は, 後に構成方程式を求める際に重要な指 針とされた.
ずり速度の更に大きいところまでの対応関係を与えるものとし $\tau$, Cox-Merz の経験則 ${ }^{17)}$

$$
\eta(\dot{\gamma})=\left|\eta^{*}(\omega)\right|_{\omega=\dot{\gamma}}=\left[\left(\eta^{\prime}\right)^{2}+\left(\eta^{\prime \prime}\right)^{2}\right]_{\omega=\dot{\gamma}^{1 / 2}}
$$

が重要である．ただし， $\eta^{*}(\omega)=\eta^{\prime}(\omega)-\mathrm{i} \eta^{\prime \prime}(\omega)=G^{*}(\omega) / \mathrm{i} \omega$ は複 素粘性率である.この関係は，ミクロ相分離するブロック共重合 体などを別にすると，高分子濃厚系では極めて良く成立する。

\section{3. からみ合いによる一時的網目理論}

\section{$3 \cdot 1$ 架橋高分子系の応力と複屈折}

本節では高分子濃厚系のレオロジーにおいて極めて重要な位置 を占める，高分子鎖のからみ合いによる一時的網目理論について 述べる，基礎になっているのは，初歩的なゴム弾性理諭である. ゴム弾性の正統的な計算では, 変形によるエントロピーの変化を 計算するのであるが ${ }^{12)}$, 応力や複屈折と鎖の配向との関係を論じ るためには，以下に述べるやり方の方がわかりやすい．

架橋高分子系に招いて，架橋点間を結ぶ鎖は，自然状態に执い て平均二㭟末端間距離が $a^{2}$ で与えられるガウス鎖とする. 架橋 高分子系は，このような鎖を単位体積当たりレ简含むものとする. 鎖の両端間を結ぶベクトルを $\boldsymbol{r}$ とする，この鎖には

$$
\boldsymbol{f}=\frac{3 k_{\mathrm{B}} T}{a^{2}} \boldsymbol{r}
$$

の張力が作用する． $k_{\mathrm{B}}$ はボルッマン定数， $T$ は絶刘温度である. 物質中に面積 $\mathrm{d} S$, 法線方向 $\boldsymbol{n}$ で決まる微小平面を考兄るとさ, ベクトル $\boldsymbol{r}$ で表される鎖で，この面を貫くものの数は $\boldsymbol{r} \cdot \boldsymbol{n} \mathrm{d} S \nu$ $P(\boldsymbol{r}) \mathrm{d} \boldsymbol{r}$ で与えられる (Fig. 3). ただし， $P(\boldsymbol{r}) \mathrm{d} \boldsymbol{r}$ は鎖の両端間 ベクトルが $\boldsymbol{r}$ と $\boldsymbol{r}+\mathrm{d} \boldsymbol{r}$ の間にある確率である. したがって, こ の面を貫いて作用する張力 $\boldsymbol{F} \mathrm{d} S$ は，

$$
\begin{aligned}
\boldsymbol{F} d S & =\int f \boldsymbol{r} \cdot \boldsymbol{n} \mathrm{d} S \nu P(\boldsymbol{r}) \mathrm{d} \boldsymbol{r} \\
& =\frac{3 \nu k_{\mathrm{B}} T}{a^{2}}<\boldsymbol{r r}>\cdot \boldsymbol{n} \mathrm{d} S
\end{aligned}
$$

で与えられる。ただし， <>は $P(\boldsymbol{r})$ に関する平均を表す。応 カテンソル $\boldsymbol{\sigma}$ の定義, $\boldsymbol{F}=\boldsymbol{\sigma} \cdot \boldsymbol{n}$ より, 架橋高分子系の応力として

$$
\boldsymbol{\sigma}=\frac{3 \nu k_{\mathrm{B}} T}{a^{2}}<\boldsymbol{r} \boldsymbol{r}>
$$

が得られる.

巨視的な物質の変形を記述するために，变形前の時刻 $t^{\prime}$ に打い $\tau \boldsymbol{r}^{\prime}=\left(x_{1}{ }^{\prime}, x_{2}{ }^{\prime}, x_{3}{ }^{\prime}\right)$ 飞あった物質点が, 変形後の時刻 $t$ には $\boldsymbol{r}=$ $\left(x_{1}, x_{2}, x_{3}\right)$ に来るとする. 鎖の両端がこの変形によって, アフ イン変形の規則に従って移動するものとすると,
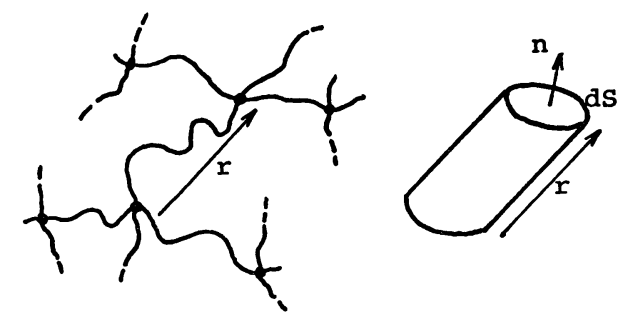

Fig. 3 Probability that crosslinking chain with end-to-end vector $\boldsymbol{r}$ (left) passes through plane with normal $\boldsymbol{n}$ and area $\mathrm{d} S$ is proportional to volume of cylinder characterized by $\boldsymbol{r}, \boldsymbol{n}$, and $\mathrm{d} S$ (right). 
の関係が成立する．ただで， $E_{i j}=\partial x_{i} / \partial x_{j}{ }^{\prime}$ は変形の勾配を表す テンソルである。これを式(11)に代入して， $\boldsymbol{r}^{\prime}$ は平衡状態に拉ける 值であるから，あらゆる方向に均等に分布しており， $\left\langle\boldsymbol{r}^{\prime} \boldsymbol{r}^{\prime}\right\rangle=$ $\left(a^{2} / 3\right) 1$ となることを考虑すると, 次式が得られる.

$$
\sigma=\nu k_{\mathrm{B}} T \boldsymbol{B}\left(t^{\prime}\right)
$$

ここで, $\boldsymbol{B}\left(t^{\prime}\right)$ は変形 $t^{\prime} \rightarrow t$ に対するフィンガーテンソルで,

$$
B_{i j}\left(t^{\prime}\right)=\sum_{k=1}^{3} E_{i k} E_{j k}
$$

によって与えられる. 一軸伸長

$$
x_{1}=\lambda x_{1}{ }^{\prime}, x_{2}=\lambda^{-1 / 2} x_{2}{ }^{\prime}, x_{3}=\lambda^{-1 / 2} x_{3}{ }^{\prime}
$$

に対しては，

$$
\boldsymbol{B}\left(t^{\prime}\right)=\left(\begin{array}{ccc}
\lambda^{2} & 0 & 0 \\
0 & \lambda^{-1} & 0 \\
0 & 0 & \lambda^{-1}
\end{array}\right)
$$

であるから， $\sigma_{11}-\sigma_{22}=\nu k_{\mathrm{B}} T\left(\lambda^{2}-\lambda^{-1}\right)$ という見慣れた式が得ら れる、単純ずり

$$
x_{1}=x_{1}{ }^{\prime}+\gamma x_{2}{ }^{\prime}, x_{2}=x_{2}{ }^{\prime}, x_{3}=x_{3}{ }^{\prime}
$$

に対しては,

$$
\boldsymbol{B}\left(t^{\prime}\right)=\left(\begin{array}{ccc}
1+\gamma^{2} & \gamma & 0 \\
\gamma & 1 & 0 \\
0 & 0 & 1
\end{array}\right)
$$

であるから， $\nu k_{\mathrm{B}} T=G_{s}$ とすれば， $2 \cdot 2$ で用いた関係 $\sigma=G_{s} \gamma$ ， $\nu_{1}=G_{s} \gamma^{2}$ などが得られる.

一方，末端間ベクトルが $\boldsymbol{r}$ で表される鎖の分極率は，

$$
\frac{3 \Delta \alpha(\boldsymbol{r r})}{5 a^{2}}+\text { isotropic term }
$$

で表される ${ }^{12)} . \Delta \alpha$ は鎖員の分極率の異方性を表す定数である. したがって，変形したゴムの分極率は

$$
\begin{aligned}
\boldsymbol{\alpha} & \left.=\frac{3 \Delta \alpha}{5 a^{2}} \nu<\boldsymbol{r r}\right\rangle+ \text { isotropic term } \\
& =\frac{\Delta \alpha}{5 k T} \boldsymbol{\sigma}+\text { isotropic term }
\end{aligned}
$$

となる．巽方性が小さいとさには分極率の主值の差は，近似的に 屈折率の主值の差と比例するから，式(18)は光弾性則を表している とみなすことができる。

\section{$3 \cdot 2$ 一時的網目理論}

高分子濃厚系中では, 高分子コイルの領域が重複しあっている ので，高分子鎖は複雑にからみ合っている．この特徴をレオロジ 一理論に導入するための考光方で, 管模型理論 ${ }^{18)}$ 以前のものは, 主に鎖の運動のまさつ係数がからみ合いによって大きくなるとす るものと，からみ合い汇よって一時的網目構造ができるとするも のである. これらの考光方に基づいて多くの理論が作られた 19).ここでは, 後の構成方程式の研究に大きな影響を及ぼした, 山本-Lodge の一時的網目理論5)を紹介する.

この理諭では，からみ合った高分子鎖は一時的な網目構造を形 成すると考光る，鎖の各部分は網目に加わったり，網目から離脱 したりしている (Fig. 4). 網目に加わった鎖は，その時点では変

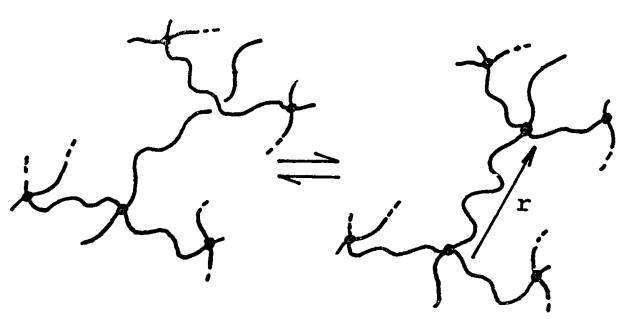

Fig. 4 Temporary crosslinking due to entanglement. Chain segment incorporated in temporary network (right) deforms and supports stress just as crosslinking chain of Fig. 3 does until it is uncrosslinked(left).

形を受けて拈らず応力に寄与しないが，その後変形を受けると， 網目構造から離脱するまで，架橋高分子中の鎖(Fig. 3) と同様に 応力に寄与すると考光る. からみ合い点は，物体の巨視的な変形 に対して,アフィン変換の規則で移動するものとする．応力は式 (11)で表されるが，架橋系と違って網目鎖のひずみはそれが生成さ れた時刻 $t^{\prime}$ によって異なっている。

さて，時刻 $t^{\prime}$ に扣いて網目に加わった一本の鎖は，応力測定の 時刻 $t$ 飞未いて網目から離れていなければ, 平均 $k_{\mathrm{B}} T \boldsymbol{B}\left(t^{\prime}\right)$ の応 力を与学 (式(13)参照). いま, $t^{\prime}$ から $t^{\prime}+\mathrm{d} t^{\prime}$ の間に網目構造に 加わり，時刻 $t$ まで離脱しないでいる鎖の数を $\nu\left(t-t^{\prime}\right) \mathrm{d} t^{\prime}$ とす ると，そのような鎖からの応力への寄与は $k_{\mathrm{B}} T \boldsymbol{B}\left(t^{\prime}\right) \nu\left(t-t^{\prime}\right) \mathrm{d} t^{\prime}$ である.ただし, 網目からの離脱の確率は, 時間差 $t-t^{\prime}$ のみの 関数と考えた。 これより時刻 $t$ に括ける応力は, 次式で与兄られ る.

$$
\boldsymbol{\sigma}(t)=\int_{-\infty}^{t} \mu\left(t-t^{\prime}\right) \boldsymbol{B}\left(t^{\prime}\right) \mathrm{d} t^{\prime}
$$

ここで, $k_{\mathrm{B}} T \nu\left(t-t^{\prime}\right) \equiv \mu\left(t-t^{\prime}\right)$ とした.

この式の性質を定常ずり流動の場合について調べよう．そのた めに式(16)に执いて， $\gamma=\dot{\gamma}\left(t-t^{\prime}\right)$ として $(16 \mathrm{a})$ より $\boldsymbol{B}\left(t^{\prime}\right)$ を求め, これを式(19)に代入すると, 次の結果が得られる.

$$
\eta=\int_{0}^{\infty} t \mu(t) \mathrm{d} t, \theta=\int_{0}^{\infty} t^{2} \mu(t) \mathrm{d} t, \beta=0
$$

すなわち, この理論では定常ずり流動の応力係数 $\eta, \theta$ は定数と なり，ずり速度依存性は導出されないまた，理論の誘導からわ かるように, 関数 $\mu(t)$ は一応任意に与えられたものであって, その形や分子量依存性を知るためには, 更に分子鎖の運動に関す る全く別の理論が必要である. このような意味で, 上述の理論は 半現象論と言うべきものである. 一方, ともあれ閉じた形の構成 方程式を与えたこと, 高分子液体に执いても架橋系同様テンソル $\boldsymbol{B}\left(t^{\prime}\right)$ が重要である点を明らかにしたことなどで，この理論が高 分子レオロジーの進歩に寄与したところは大さい。なお，一時的 網目構造の光学的異方性に関しても, 架橋系と同じ式(18)の第二式 が得られることは, 式(18)の導出過程を見れば推察できるであろう.

\section{$3 \cdot 3$ 現象論的構成方程式}

1960年代の半ばごろから，高分子濃厚系のレオロジーの研究は, 粘弾性と非線型性を統一的に报 うこと.すなわち, レオロジー的 性質を統一的に記述するための基礎方程式である構成方程式を追 求する段階に入る，物質の構成方程式として許される方程式の形 式は無限に存在するが20), 高分子濃厚系に関する限り, 式(19)のよ うな形が優れていることがかなり早くから認められていた，その 
ため実際に詳細に調べられたのは，式(19)を修正した次の形の方程 式に限られていた。

$$
\boldsymbol{\sigma}(t)=\int_{-\infty}^{t} \mu\left[t-t^{\prime}, X\left(t^{\prime}\right)\right]\left[\boldsymbol{B}\left(t^{\prime}\right)+\varepsilon \mathbf{C}\left(t^{\prime}\right)\right] \mathrm{d} t^{\prime}
$$

ただし， $\mathbf{C} \equiv \boldsymbol{B}^{-1}$ はコーシーテンソルである. この項は，ずり流 動に扣いて恒等的に $\nu_{2}=0$ となるのを防ぐために導入されたもの である. 記憶関数の中の変数 $X\left(t^{\prime}\right)$ は非線型性, 例变ば粘度のず り速度依存性等を表すために導入されたものであって(式(20)参照)， 流動に関する適当なスカラ一量を意味する， $X\left(t^{\prime}\right)$ として実際に 詳しく調べられたのは, 時刻 $t^{\prime}$ に打ける变形速度の不変量, 抢上 び変形 $t^{\prime} \rightarrow t$ に対するテンソル $\boldsymbol{B}\left(t^{\prime}\right)$ の不変量である. 変数 $X\left(t^{\prime}\right)$ の適切な選び方に関する膨大な実験的研究については，4 - 2 亿 おいて粗筋だけ述べる，詳細については総説20),21)を参照するこ とができる，結論だけ述べて扔くと，高分子濃厚系に関しては $X\left(t^{\prime}\right)$ として変形の不変量を選ぶと, 極めて多様な流動履歴に対 する応力挙動が, 武(21)によってうまく記述される.

\section{4. 非定常流のレオロジー}

\section{$4 \cdot 1$ 構成方程式研究のための新しい測定技術}

粘弾性と非線型性を統一的に記述する構成方程式を求めるため には, 非定常の流動に抢ける非線型挙動を測定することが必要で ある．研究の初期に打いては，定常ずり流動の測定のために開発 された装置をとのまま用いて, 非定常流の応力が測定された. 法 線応力差は, 主に円錐一円板型レオメータの全推力として測定さ れていたのであるが，この方法で非定常での測定を行うと測定值 に時間的な遅れが生じることが，Meissnerによって指摘された 全推力の変化に伴って円錐と円板の間隙が変化する（この微小な 変化が全推力の变化として測定される）際に, 間隙の半径方向に 液体の二次的流動が生じ，この流動のために間隙の変化に遅れが 生じるのである.

二次流動による間吵变化の緩和時間 $\tau_{\mathrm{D}}$ は, 次の関係を満た す23).

$$
\tau_{\mathrm{D}}=\frac{6 \pi \eta R}{K \delta^{3}}
$$

ここで, $\eta$ は試料の粘度 $(\dot{\gamma} \rightarrow 0$ に抢ける)，Rは円板の半径， $\delta$ は間隙角， $K$ は円錐と円板を支えるわく組と，推力検出用バネを 合わせた系の強さ (力/変形量) を表す量である. 実際に遅れを 減少させるには $R$ を小くすること， $\delta$ をさくすること（ただ

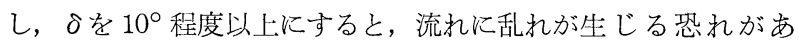
る，Kを大きくすることが有效であることが，実験的に示され た 22),23).Kを大きくするためには，装置の放く組を太くし，末 た力検出器として変形の小さい压電素子を用いることなども行わ れた ${ }^{24)}$. 最近では, これらの点を可能な限り考慮した装置も市販 されており, 比較的低粘度の試料については, 非定常流の法線応 力差の測定は可能と信じられている. 在来の装置の改造も, 新し い装置も概して極度に高価でめる。

一方, 定常流に扔いて証明された流動複屈折の関係式(6)によっ て, 非定常流の法線応力差を求めることも試みられた. この方法 では, 二次流動のために測定值に遧れが生じるということはない その代わりに, 時時刻刻変化する複屈折 $\Delta n$ と消光角 $\chi$ を測定す る方法，扣よび基礎となる式(6)が非定常状態でも成立するかとい
ろ二つの点が問題になる．第一の点は二つの手法で解決された. Janeschitz-Kriegl $5^{25)}$ は定常流用の複屈折装置を用いて, 非定常

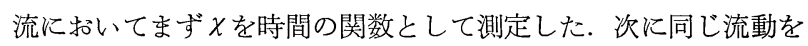
繰り返し, 各時点に括いて既に得られている $\chi$ の值を用いて, 定 常流と同じ方法で $\Delta n$ を測定した. 尾崎ら ${ }^{26)}$ は交差させた偏光膜 の間に試料を置き, 透過光強度を時間の関数として測定した. 偏 光軸と流動方向の間の角度を変えて反復測定した光強度から, $\Delta n$ とメを求めることができる.

非定常流に括いても式(6)が成立することは, 同じ条件下で測定 されたずり応力 $\sigma$ と $\Delta n \sin 2 \chi$ の比例関係から確かめられる. 今 までに調べられたポリスチレンの溶融体および濃厚溶液では, こ の比例関係がよく成立し, 光弾性係数 $C$ は定常流に执いて得られ た值と一致することが確認された．液晶のような異方性の液体, 流動によって構造が変化するような液体，抢よび鎖員の局所的な 配位が平衡から著しくずれるような高い周波数の運動等を別にす ると，非定常流に捻いても式(6)は成立するものと予想されるので, 流動複屈折法は非定常の応力測定法として有効である. 高粘度の 系における測定にはありふれた引張り試験機を用いることもでき， 低粘度の系よりもむしろ容易である ${ }^{27)}$.

階段型ずり变形後の第一法線応力差の測定結果 ${ }^{26)}$ を, Fig. 6r 例として示す. 階段型ずり変形は式(16)の ととして, Fig. 5亿示す ような階段型に变化する值を入れたものであって, 後述のように, ひずみ依存型構成方程式に関して重要な位置を占める変形履歴で ある. Fig. 6 には比 $\nu_{1} / \sigma$ を示す. 対応するのの值については, Fig. 7 に示す. Fig. 6 の結果は,

$$
\nu_{1} / \sigma=\gamma
$$

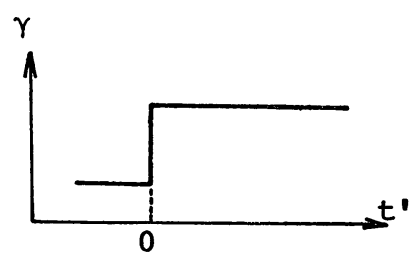

Fig. 5 Step-shear deformation.

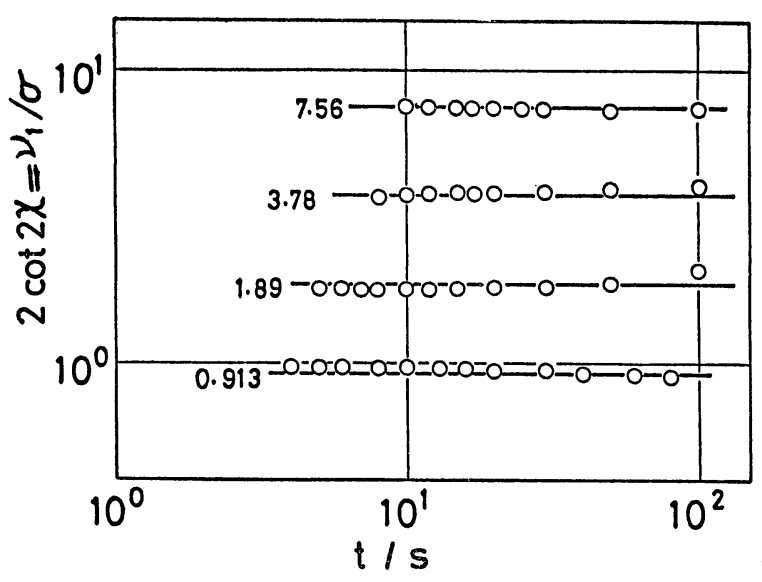

Fig. 6 Ratio $\nu_{1} / \sigma$ measured after applying step-shear to $8 \%$ solution of polystyrene (molecular weight 3.0 $\left.\times 10^{6}\right)$ in chlorinated biphenyl at $30^{\circ} \mathrm{C}$. Solid lines represent magnitudes of shear given at left side of each group of data. 
の関係が成立することを示している．この関係は，高分子濃厚系 が式(21)等で表されるような共变形型28)の記憶流体であって, 共回 転型でないことを意味する. 一時的網目理論の立場から見ると， 階段型変形の際に鎖がアフィン変形するならば,すべての網目鎖

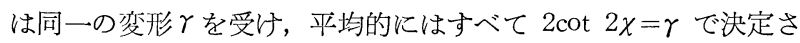
れる方向に配向する．したがって，たと光網目鎖ごとに緩和速度 が異なっていても, 別の配向角が観測されることはない，一方， 例えば定常流の場合には，より以前に生成された $\left(t-t^{\prime}\right.$ が大き

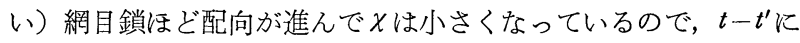
従っていろいろな $\chi$ の值の鎖が混在する. 定常流停止後の応力緩 和時には， $\chi$ は時間とともに減少 $\left(\nu_{1} / \sigma\right.$ は増加）する.

構成方程式研究に関連した測定技術で，もう一つの注目すべき ものは，溶融体の定ひずみ速度に抽ける伸長である，これは式(15) に执いて， $\lambda=\mathrm{e}^{\imath\left(t-t^{\prime}\right)}$ としたものである．単純な方程式(19)を用い て，伸長粘度 $\eta_{t}$ を計算してみると，

$$
\begin{aligned}
\eta_{t} & =\left(\sigma_{11}-\sigma_{22}\right) / \dot{\varepsilon} \\
& =\frac{1}{\dot{\varepsilon}} \int_{-\infty}^{t} \mu\left(t-t^{\prime}\right)\left[\mathrm{e}^{2 \hat{\varepsilon}\left(t-t^{\prime}\right)}-\mathrm{e}^{-\hat{\varepsilon}\left(t-t^{\prime}\right)}\right] \mathrm{d} t^{\prime} \\
& =\frac{1}{\dot{\varepsilon}} \int_{0}^{\infty} \mu(t)\left(\mathrm{e}^{2 \hat{t} t}-\mathrm{e}^{-\hat{\varepsilon} t}\right) \mathrm{d} t
\end{aligned}
$$

となり,ひずみ速度 $\dot{\varepsilon}$ が記憶関数 $\mu(t)$ の最大緩和時間の逆数の $1 / 2$ を越えると，無限大になってしま5。すなわち，伸長流動に おいては, ずり流動举動からは想像できないような非線型挙動が 出現する可能性があり, 構成方程式の研究上極めて興味深いもの である。

定速伸長に和ける測定法は, Meissner を始めとする BASF の 研究者によって精力的に研究された ${ }^{29), 30)}$. ひずみ速度一定の伸 長は，一定間隔に配置された 2 対のローラーによる定速巻き取り， あるいはコンピューターによるモーターの回転数の制御（速度を 指数関数的に增加）によって実現される. 定速ひずみの実現の外 に，細い液体試料をたわまない上万に保持すること，変形が進行 して極度に細くなった試料の微小な張力を測定することなどが困 難な点であった．現在ではこれらの問題がある程度解決され，市 販の装置があり，本邦でも何台かの装置が試作されている. Meissnerらによる測定結果は，一応ひずみ依存型構成方程式で記 述されることが示されたが31)，伸長変形挙動の詳細については， 今後の研究に待つ所が大きい.

\section{$4 \cdot 2$ 種々の流動履歴}

高分子濃厚系の構成方程式の良否を判定するための基準とされ たのは，大体次に示すような流動挙動である．これらの流動挙動 の測定や，構成方程式との関連の詳細については，幾つかの総説 そまとめられている32,20),21).

(i) 線型粘弾性, 例えば複素弾性率 $G^{*}(\omega)=G^{\prime}(\omega)+\mathrm{i} G^{\prime \prime}(\omega)$. これによって，式(21)の記憶関数 $\mu(t, X)$ の微小変形に和ける極 限 $\mu(t, 0)$ の形が決定される.

（ii）定常ずり流動を表す関数 $\mu(\dot{\gamma}), \theta(\dot{\gamma})$ 打よび $\beta(\dot{\gamma})$.

(iii) ずり速度一定のずり流動開始時の応力成長. ずり速度 $\dot{\gamma}$ が大きい場合には，ずり応力 $\sigma$ も第一法線応力差 $\nu_{1}$ も，最初增 加して極大を経てから定常值に近づく（ストレスオーバーシュー r).

（iv）定常ずり流動停止後の応力緩和. 緩和初期においては, $\sigma$ は $\nu_{1}$ よりも急激に緩和する。
この外に測定例は多くないけれぞも，大振幅の振動，定常ずり 之微小振動の重畳, 定速ずりの断続，定常ずり停止後の弾性的回 復等の連続的ずり流動履歷が研究されている.

（v）階段型ずり，2段階の階段型ずり。ひずみ依存型構成方 程式の優位性の確立括よびその欠宿の発見に関して，決定的な意 味を持った流動履歴である。この履歴については後述する。

（vi） 定速単純伸長，その開始時の過渡的挙動，停止後の弾性 的回復. 伸長流動の特異性については，式(24)のところで説明した と扮りである。

ここでは，構成方程式の比較検討については省略して，ひずみ 依存型構成方程式によって，応力の予測ができることの例を示す. 流動様式を単純ずり（式(16)）だけに限ると, 変形履歴は時刻 $t^{\prime}$ か ら $t$ までのずりの大きさ $\gamma\left(t^{\prime}\right)$ で代表される. 式(21)に括いて $X\left(t^{\prime}\right)$ として変形の不変量を選ぶと，ずり応力执よび第一法線応力差は， 次のような形で与えられる.

$$
\begin{aligned}
& \sigma(t)=\int_{-\infty}^{t} \mu\left(t-t^{\prime},\left|\gamma\left(t^{\prime}\right)\right|\right) \gamma\left(t^{\prime}\right) \mathrm{d} t^{\prime} \\
& \nu_{1}(t)=\int_{-\infty}^{t} \mu\left(t-t^{\prime},\left|\gamma\left(t^{\prime}\right)\right|\right)\left[\gamma\left(t^{\prime}\right)\right]^{2} \mathrm{~d} t^{\prime}
\end{aligned}
$$

ここで, Fig. 5 そ示すような階段型ずりを考光ると,

$$
\frac{\sigma(t)}{\gamma}=\frac{\nu_{1}(t)}{\gamma^{2}}=\int_{t}^{\infty} \mu\left(t^{\prime}, \gamma\right) \mathrm{d} t^{\prime}
$$

が得られる．ひずみ依存性緩和弾性率を $G(t, \gamma) \equiv \sigma / \gamma$ で定義す ると, 記憶関数 $\mu(t, \gamma)$ は, 次式によって容易に求めることが できる.

$$
\mu(t, \gamma)=-\partial G(t, \gamma) / \partial t
$$

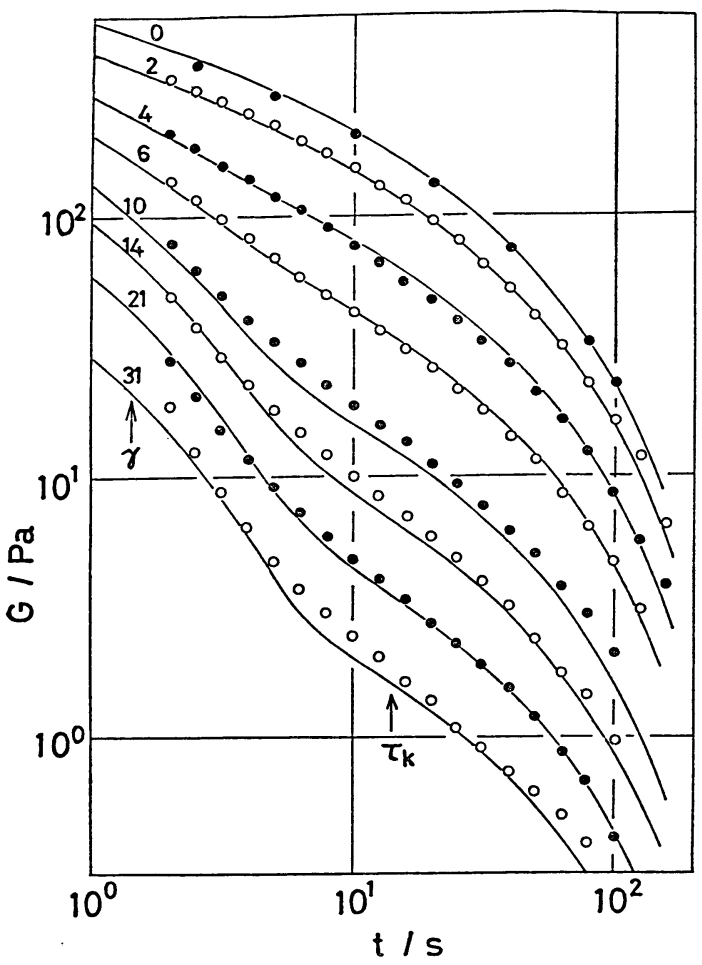

Fig. 7 Strain-dependent relaxation modulus for the same polystyrene solution as in Fig. 6. Circles represent measured values and curves represent approximate function used for calculations of Fig. 8 and 9. 


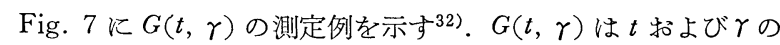
減少関数であって, 多くの場合

$$
G(t, \gamma)=\sum_{p} G_{p} \exp \left(-\alpha_{p} \gamma-t / \tau_{p}\right)
$$

の関数形を仮定して, 定数 $G_{p}, \alpha_{p}, \tau_{p}$ を適当淀めると, 測定 值をうまく表すことができる．Fig. 7 の実線は，このよ5にして 求めた近似関数である. この近似関数を用いて, 式(25)〜(27)によっ て子測された結果と観測結果の例をFig. 8，9 亿示す. Fig. 8 は 定常ずりに関する結果, Fig. 9 は定速ずり流動の開始時に执ける 応力成長に関する結果で， $\nu_{1}$ はいずれも複屈折法によって測定さ れたものである。階段型変形といら全く異なった流動履歴に対す

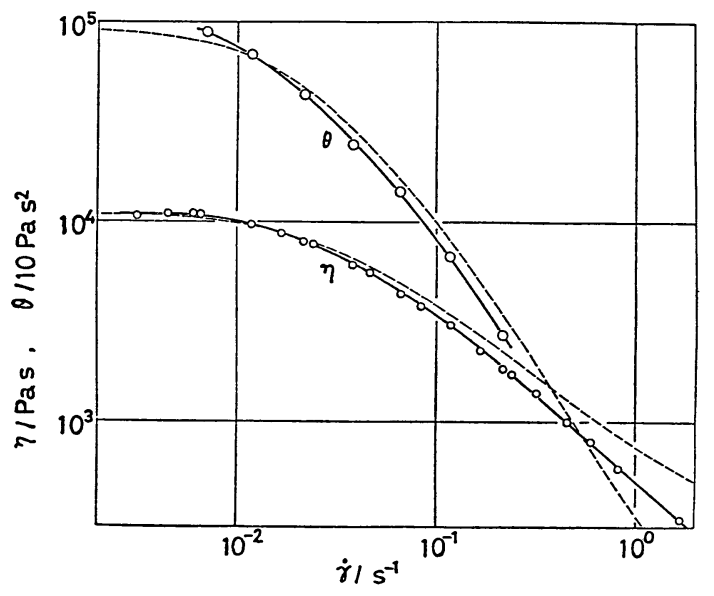

Fig. 8 Quantities $\eta$ and $\theta$ for the same polystyrene solution as in Fig. 6 and 7. Circles represent measured values. Dashed lines represent results calculated from the strain-dependent constitutive equation and memory function derived from relaxation modulus.

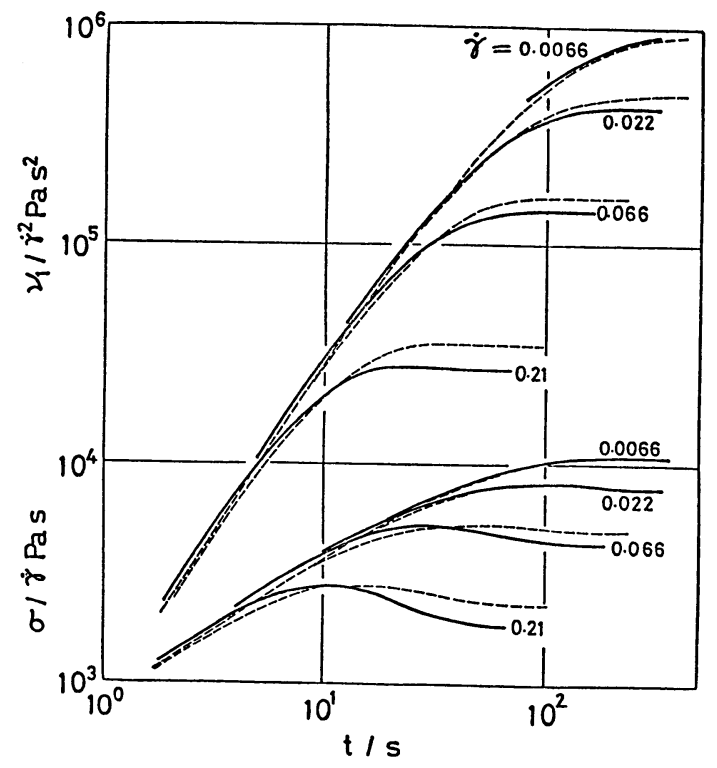

Fig. 9 Shear stress $\sigma$ and first normal stress difference $\nu_{1}$ at the start of shear flow for the same polystyrene solution as in Fig. 6 through 8. Solid lines represent measured values and dashed lines calculated results as described in caption of Fig. 8.
る举動から得られた予測值と実測値の一致はかなり良好である.

本項の始めに挙げた各種の流動履歴に対して，大体同程度の 予測が可能である，後に述べるような向きの变化する流動を除け ば，ひずみ依存型構成方程式は，高分子濃厚系のレオロジー挙動 をほぼ正しく表しているものと考えられている.

\section{$4 \cdot 3$ 階段型ずり}

上の議論で明らかなように，ひずみ依存性緩和弾性率 $G(t, \gamma)$ は，高分子濃厚系のレオロジーに関する情報をほとんど完全に含 む基本的な関数である. 分子量分布の狭い線状高分子濃厚系の $G(t, \gamma)$ の典型的な例は Fig. 7 亿見ることができる. $G(t, \gamma)$ は $t$ 抢よび $\gamma$ の減少関数である. $\gamma$ によ $G(t, \gamma)$ の減少の程度は $t$ が大きい活ぞ大きく，ある時間（図で $\tau_{k}$ と記した）以上の長 時間域に打いては,

$$
G(t, \gamma)=h(\gamma) G(t)
$$

のよ5に変数分離形で表すことができる。ここで， $G(t)$ は線型 の緩和弾性率である．この結果は，最大緩和時間がひずみに依存 しないことを示している．実際，定常流停止後ののあるいは $\nu_{1}$ から求めた最大緩和時間も，ずり速度に依存しない。これは単分 散線状高分子系の重要な特性である.

ひずみ依存性を表す関数 $h(\gamma)$ の例 ${ }^{33)}$ を Fig. 10 に示す．この 図からも推定されるように，ある濃度一分子量の範囲の試料にわ たって， $h(\gamma)$ は共通である. 他の物質に関する結果も比べて見 ると, 分子量, 濃度が極度に高くない限り, $h(\gamma)$ は物質種にも 依存しない普遍的な関数であって, 变形の幾何学的因子によって 決定されるものであると推定される．この点は後にDoi-Edwards 理論によってみごとに説明されることになった． $h(\gamma)$ が普遍的 関数になる限界は, 大体 1 分子当たりのから又合い点の数が 50 筒 以下と考学られている ${ }^{33), 34)}$. 普遍的関数からずれることの原因 は現在のところ不明である.

階段型変形のもう一つの重要性は，ひずみ依存型構成方程式の 欠陥の発見につながったことにある.Fig. 11 に示すように 2 段 階に変化するずり変形を考学る，第一のずりの大きさを $\gamma_{1}$ (Fig. $11 \mathrm{a}$ では正， b， c では負）とし，その時刻を $-t_{1}$ とする．第二 のずり $\gamma_{2}$ (正) は, $t=0$ に印加されるものとして， $t>0$ に批りる

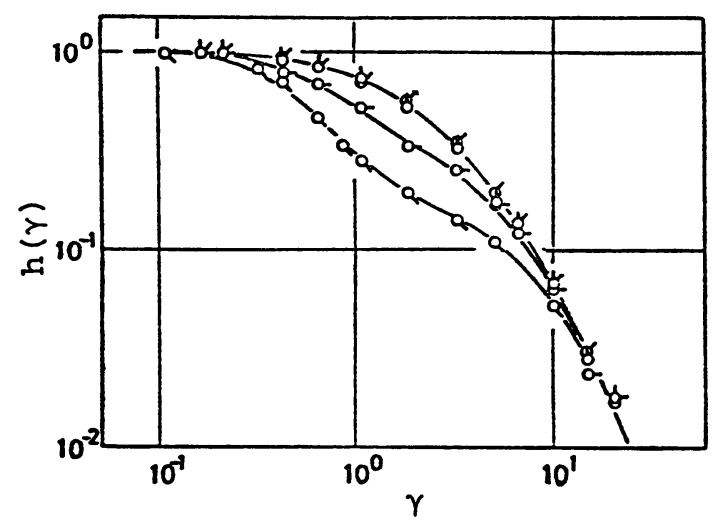

Fig. 10 Strain-dependent function $h(\gamma)$ for solutions of polystyrene (molecular weight $7.62 \times 10^{6}$ ) in diethyl phthalate with various concentrations; pip up, $0.112 \mathrm{gcm}^{-3}$ and successive $45^{\circ}$ rotations clockwise of pips correspond to $0.139,0.176$, and $0.221 \mathrm{gcm}^{-3}$. 


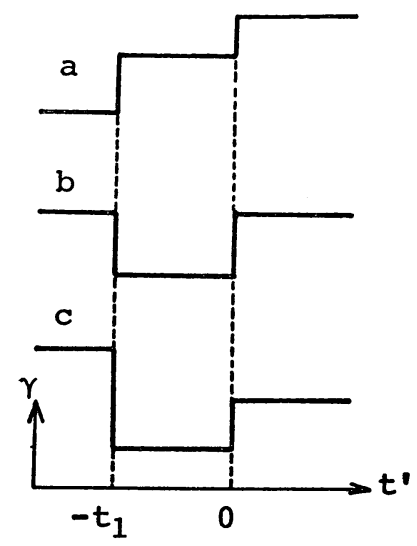

Fig. 11 Examples of double-step shear deformation.

応力を測定する。ひずみ低存型構成方程式によれば，例えばずり 応力は,

$$
\sigma(t)=\sigma\left(t+t_{1}, \gamma_{1}+\gamma_{2}\right)+\sigma\left(t, \gamma_{2}\right)-\sigma\left(t+t_{1}, \gamma_{2}\right) \quad \text { (30) }
$$

のように表される，ただし，右辺の $\sigma(t, \gamma)$ は一段階ずりに対す るずり応力である， $\nu_{1}, \nu_{2}$ についても同様な関係が成立する.

この式による予測結果は，変形の向きが同一 $\left(\gamma_{1}>0\right)$ のときに は，観測值と良く一致する。一方， $\gamma_{1}=-\gamma_{2}$ (Fig. 11b)のときに は，予測值は過小であり ${ }^{35)}$ ，ひずみ依存型構成方程式が適用でき ないという結果が得られた．更に一般的に， $\gamma_{1}<0$ の場合には類 似の不一致が存在することが明らかにされた．Fig. 12 には， $\gamma_{1}$ $=-2 \gamma_{2}$ (Fig. 11c) の場合の結果 ${ }^{36)}$ を示す. 破線で示すのはひず 及依存型構成方程式を用いて，一段階ずりに対する結果から得ら れた予測值である。ずり応力に関しては，測定值と大きくずれて いることがわかる.

この 2 段階変形に関する結果をきっかけとして，伸長流動停止

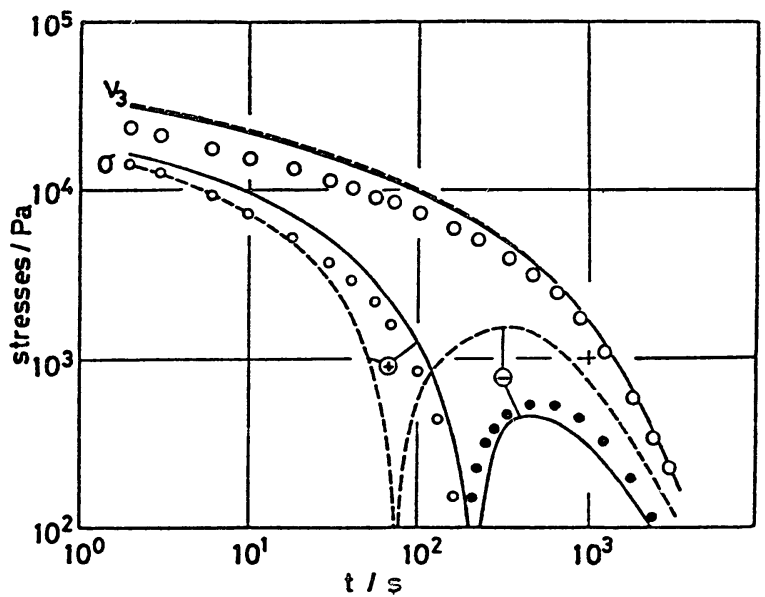

Fig. 12 Shear stress $\sigma$ and normal stress difference $\nu_{3}$ $\left(\equiv \nu_{1}+\nu_{2}\right)$ after double-step shear of $-\gamma_{1}=$ $2 \gamma_{2}=2.9$ and $t_{1}=200$ s for polystyrene solution in chlorinated biphenyl ; molecular weight of polymer is $6.7 \times 10^{5}$ and concentration is 0.4 $\mathrm{gcm}^{-3}$. Filled circles imply negative values. Dashed line represent prediction of straindependent constitutive equation and solid line that of Doi-Edwards theory. The latter is supposed to be applicable only at long times.
後の弾性的回復や, 大振幅の振動の場合にはひずみ依存型構成方 程式によってレオロジー挙動がうまく表されないことが明らかに された．これらの流動は，流動の向きが途中で逆転することで特 徵づけられる.これらの理論からの偏移は, Doi-Edwards 理論に 含まれる微妙な数学的仮定 (Independent Alignment Assumption と呼ばれる）の評価を行う際の有効な基準を与えることとなっ $た^{37), 38)}$.

2 段階変形の場合，鎖の配向について興味深い結果を得ること ができる ${ }^{39)}$. 第 3 節での考察から明らかなよ 5 に, 複屈折の消光 角 $\chi$ は，鎖の平均的な配向方向を示している．2 段階変形の場合 には $t^{\prime}<-t_{1}$ に括いて形成された網目は $\gamma_{1}+\gamma_{2}$ の変形を受け， $-t_{1}<t^{\prime}<0$ に打いて形成された網目は $\gamma_{2}$ の变形を受ける。従っ て網目鎖は，それぞれ

$$
\chi_{1}=\frac{1}{2} \cot ^{-1} \frac{\gamma_{1}+\gamma_{2}}{2}, \quad \chi_{2}=\frac{1}{2} \cot ^{-1} \frac{\gamma_{2}}{2}
$$

の二つの方向に配向した二群に大別することができる，これを用 いると， 2 段階変形後の応力は次のように表すことができる（式 (6)参照).

$$
\begin{aligned}
& 2 \sigma(t)=\Delta \sigma_{1}(t) \sin 2 \chi_{1}+\Delta \sigma_{2}(t) \sin 2 \chi_{2} \\
& \nu_{1}(t)=\Delta \sigma_{1}(t) \cos 2 \chi_{1}+\Delta \sigma_{2}(t) \cos 2 \chi_{2}
\end{aligned}
$$

いま，平面上のベクトル $\left(\nu_{1}, 2 \sigma\right)$ を考えると，これは大きさ $\Delta \sigma_{1}$, 方向 $2 \chi_{1}$ と，大きさ $\Delta \sigma_{2}$, 方向 $2 \chi_{2}$ の二つのベクトルの和にな っている. $\nu_{1}(t)$ と $\sigma(t)$ の測定值から， $\Delta \sigma_{1}(t), \Delta \sigma_{2}(t)$ を分離 評価することができる。

Fig. 13 に示すのは Fig. 12 の実験（および $t_{1}$ の異なる実験） で得られた結果を，横軸に $\nu_{1}$, 縦軸に $2 \sigma を$ 取ってグラフにした

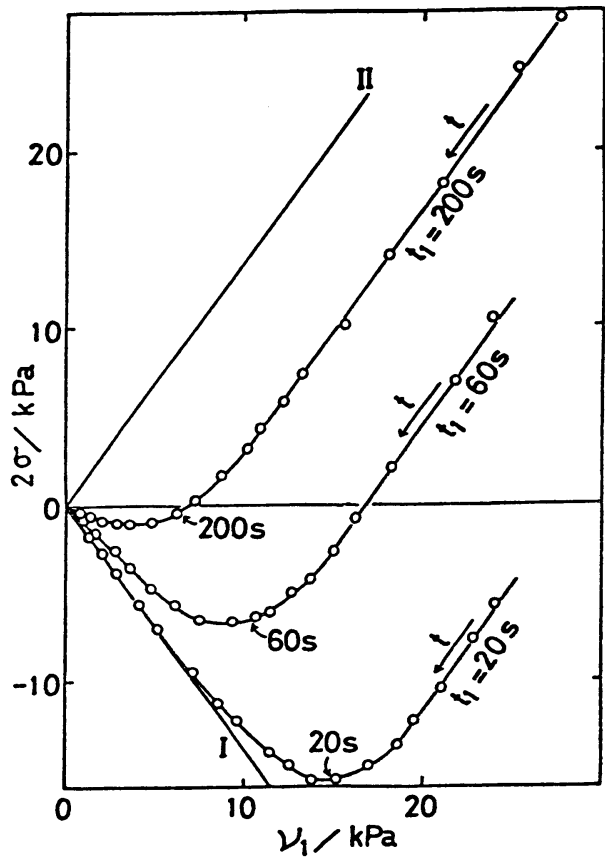

Fig. 13 Plot of $2 \sigma$ against $\nu_{1}$ for double-step shear deformations of $-\gamma_{1}=2 \gamma_{2}=2.90$. For each value of $t_{1}$ data points approach origin from right as time $t$ passes. Curved arrows indicate points where $t=t_{1}$. Lines I and II make angles $\cot ^{-1}\left[\left(\gamma_{1}+\gamma_{2}\right) / 2\right]$ and $\cot ^{-1}\left(\gamma_{2} / 2\right)$, respectively, with abscissa. 
ものである. 直線 I, II と横軸との間の角度は, それぞれ $2 \chi_{1}$ 打 よび $2 \chi_{2}$ である. 観測点は, 時間 $t$ の進行に従って右方から原点

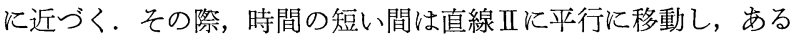
時点で急に方向を変えて, 直線に漸近する.この結果は, $\Delta \sigma_{2}$ が短時間の間に急激に緩和するのに対して， $\Delta \sigma_{1}$ は短時間では緩 和せず， $\Delta \sigma_{2}$ が注とんど緩和し終ってから緩和することを示して いる. 遠い過去 $\left(t^{\prime}<-t_{1}\right)$ に形成された網目からの忍力への寄与 $\Delta \sigma_{1}$ と, 近い過去 $\left(-t_{1}<t^{\prime}<0\right)$ からの寄与 $\Delta \sigma_{2}$ の緩和が，この ように分離しているということは, 網目の生成消隇を考学る上で 興味深い.

\section{Doi-Edwards 理論}

\section{$5 \cdot 1$ 理論の概要}

Doi-Edwards 理論1)については本号に解説があり ${ }^{40)}$, 実験との

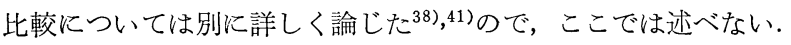
ここでは一時的網目理論による Doi-Edwards 理論の解釈, およ びそれに必要なだけ理論に用いられている分子模型について述べ る.

この理論はde Gennes の管模型18) と基ついているのであるが, 以下の考察のためには, 理論の中途で導入された滑り環模型1)を 考学れば十分である. そこで, 高分子濃厚系中には滑り環がラン ダムに浮かんで扣り，高分子鎖は一連の環を次々に貫いていると する (Fig. 14). 環は物体の変形に従ってアフィン的に移動する

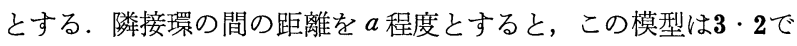
紹介した一時的網目模型に良く似ていることがわかる．環と環を つなぐ鎖は，網目を構成する網目鎖とみなすことができる，この 模型では，鎖が環に沿って滑ることはできるが，鎖の末端以外で は一連の環群から脱け出して形を変えることはできないのが特徵 的である.

さて, 物体を変形すると滑り環は移動し, 鎖は伸びかつ配向す る. 一方, 管模型理論では鎖の長さは短時間の5号に平衡值をで もどってしまうので, 張力は式(9)の代わりに平衡值と同じ大きさ の

$$
\boldsymbol{f}=\frac{3 k_{\mathrm{B}} T}{a} \frac{\boldsymbol{r}}{|\boldsymbol{r}|}
$$

で表されることになる，配向は鎖が一連の環から抜け出すをで失 われない，鎖は平衡の長さを持ち，配向した状態になっている. このような系の応力は, 式(11)の代わりに

$$
\boldsymbol{\sigma}=3 \nu k_{\mathrm{B}} T\left\langle\frac{\boldsymbol{r} \boldsymbol{r}}{|\boldsymbol{r}|}\right\rangle /\langle|\boldsymbol{r}|\rangle
$$

で与兄らる。，本論文に执いてはわかりやすくするために，多少 正確さを犠牲にして,

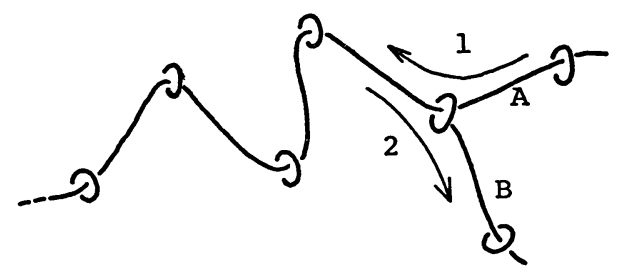

Fig. 14 Slip-link model of Doi and Edwards.

$$
\left\langle\frac{\boldsymbol{r} \boldsymbol{r}}{|\boldsymbol{r}|}\right\rangle /\langle\mid \boldsymbol{r}\rangle \simeq \frac{\langle\boldsymbol{r} \boldsymbol{r}\rangle}{\left\langle|\boldsymbol{r}|^{2}\right\rangle}=\frac{\boldsymbol{B}\left(t^{\prime}\right)}{\operatorname{tr} \boldsymbol{B}\left(t^{\prime}\right)}
$$

と近似する。ただし， tr $\boldsymbol{B}$ は $\boldsymbol{B}$ の跡である。式(34)からは，

$$
\boldsymbol{\sigma}=3 \nu k_{\mathrm{B}} T \frac{\boldsymbol{B}\left(t^{\prime}\right)}{\operatorname{tr} \boldsymbol{B}\left(t^{\prime}\right)}
$$

が得られる. 式(36)と(13)を比較すると，鎖の張力が早く緩和してし ま うために, 応力への効率が $3 / \operatorname{tr} \boldsymbol{B}$ 倍に低下寸ることがわかる. これが Doi-Edwards 理論に抢ける非線型性の起因である。この 因子はずり変形の場合には $\left(1+\gamma^{2} / 3\right)^{-1}$ であって, Fig. 10 に示 した $h(\gamma)$ の普遍的な関数とほぼ一致する.

さて, 鎖は環に沿って前後へ運動し, 末端から順に別の環へ移 る. Fig. 14 でまず 1 の方向へ進み, その後 2 の方向へ進むと, $A$ で表される「網目鎖」は $B$ に移る. $A$ は最初の変形により一定 方向に配向しているが， $B$ には変形の影響は存在しない。したが って, 配向している鎖の数 $は$ は時間とともに減少し, 応力は緩和 する.一時的網目理論の考方方では, 配向した網目鎖 $A$ が消隇し て，平衡状態の網目鎖 $B$ が生成したことになる，管模型ではこの 現象が分子鎖の末端で生じるのが特徴である. 式(36)によれば， 1 箇の網目鎖からの応力への寄与は $3 k_{\mathrm{B}} T \boldsymbol{B}\left(t^{\prime}\right) / \operatorname{tr} \boldsymbol{B}\left(t^{\prime}\right)$ で与えら れる.したがって， $t^{\prime}$ から $t^{\prime}+\mathrm{d} t^{\prime}$ の間に一連の環から抜け出し て別の環に入り，その後時刻 $t$ まで新たに入った環から抜け出さ ない「網目鎖」の数を $\nu\left(t-t^{\prime}\right) \mathrm{d} t^{\prime}$ とすると，応力は

$$
\sigma(t)=\int_{-\infty}^{t} 3 k_{\mathrm{B}} T \nu\left(t-t^{\prime}\right) \boldsymbol{B}\left(t^{\prime}\right) / \operatorname{tr} \boldsymbol{B}\left(t^{\prime}\right) \mathrm{d} t^{\prime}
$$

で与えられる. 関数 $\nu(t)$ は管模型理論によって与えられるが, ここでは省略する。式(37)は式(35)の近似を用いているが，DoiEdwardsによって導かれた結果に近く, 形が単純であるので理論 の結果を概観するには便利である，一見してわかるように，式(37) は式(21)の形をして沏り，ひずみテンソル $\boldsymbol{B}\left(t^{\prime}\right)$ の第一不変量 $\mathrm{tr}$ $\boldsymbol{B}\left(t^{\prime}\right)$ を変数 $X\left(t^{\prime}\right)$ とするひずみ依存型構成方程式である.

このように, Doi-Edwards 理論の結果は管模型理論と一時的網 目理諭の考え方から, 比較的簡単に導き出すことができる. 変形 の向きが変化するような場合については理諭は複雑となり, 式(37) のような閉じた構成方程式は得られない。このような場合の複雑 さの原因は, 別報 ${ }^{38)}$ にわかりやすく解説されている.

\section{$5 \cdot 2$ 管模型理論の実証}

上に一部紹介した Doi-Edwards 理論は, 第 4 節までに述べた ような線状高分子濃厚系の非線型粘弾性挙動をかなり良く記述す ることができる. 現在では, この理論を分子量分布の広い系 ${ }^{22}$ や 分岐高分子系 ${ }^{43)}$ まで拡張することなどが試みられている.

一方, 理諭の基礎となる管模型理論においては, 分子鎖が自分 自身に沿った管形領域内で運動すると仮定されるのであるが，こ のよ5な運動様式は, 実際の高分子濃厚系に执いて実証されてい るのであろうか．筆者はこの答えは否であると判断している．管 模型理論から導かれた多くの予測は, 観測結果とかなり良く一致 する. 例觉ば, 濃厚系中に猢る高分子の自己拡散係数は, 分子 量の 2 乗に逆比例することが予測されるが，これは実験的に証明 されている. 一方, 分子鎖が自分自身に沿って運動することを証 明するための実験は数少なく, 今までのところ十分良い実験も行 われていない。

Richter ら $^{44)}$ は, 高分子濃厚系の準弾性中性子散乱から, この ような運動を検出しょうと試みたが，管模型で予想されるような 
運動様式は全く検出されず, 逆に稀薄溶液中で見られるような運 動のみが観測された. しかしながら，この結果は用いた試料の分 子量が低すぎることに起因する可能性が濃い。試料の分子量を增 加させると, 測定波長怙よび時間を増加させなければならないの で，この方法による測定は現在の中性子散乱装置の能力の丁度限 界くらいに相当すると考えられる.

Boué ら ${ }^{45}$ は式(33)の上で述べた伸長鎖の長さの平衡過程（配向 の変化しない収縮, これは Doi-Edwards 理論に特徴的な仮定で ある）を，中性子散乱法で観測しょうとした．膨大な試みにかか わらず，現在までのところ予想されたような収縮は観測されてい ないこの収縮はレオロジーに括ける非線型性の起源とされ，多 くの非線型現象がこれによって説明されていることを考劣ると, 中性子散乱の結果は不思議と言わざるをえない. Boué らの実験 に関しては, 試料の分子量分布に関して不安があり，より良い試 料による追試が望まれる.

このような現状に扣いて，管模型理論で仮定された分子運動を 実証することは，レオロジー理諭の基礎として極めて重要であろ 5. 中性子や光の散乱法による研究については, 多くの研究者に よって論じられているので，ここでは複屈折法を用いた研究法を

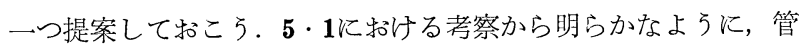
模型理論では式(32)に扣ける $\Delta \sigma_{1}$ は分子鎖の中心近く, $\Delta \sigma_{2}$ は末 端近くからの応力への寄与を示している. Fig. 13 の測定值で, 右方の直線部分は分子末端に括ける配向の緩和を, 原点付近は分 子中央部の緩和を表しているはずである。いま ABA 型のブロッ ク共重合体を考元て, 例えばA成分については鎖員の分極率の異 方性 $\Delta \alpha$ が0になるものを選ぶ（式(17)参照）(これはA成分とし て適当な共重合体をとると実現できる。例えば，ポリスチレンで は $\Delta \alpha<0$, ポリメタクリル酸メチルでは $\Delta \alpha>0$ であるから, 適 当な混合比の共重合体では $\Delta \alpha \simeq 0$ となるであろう).このような 物質について 2 段階変形後の複屈折を測定すると，これはB成分 だけの配向を測定していることになる. $\Delta n \cos 2 \chi$ に対して $\Delta n$ $\sin 2 \chi$ をプロットすると, Fig. 13 に相当するグラフが得られる。 $t_{1}$ があまり大きくなれば，管模型型の分子運動の場合には，鎖の 中心部は $\chi_{1}$ の方向に配向しているはずであり, 測定点は原点を 通り，横軸との間の角度が $2 \chi_{1}$ である直線上に並ぶであるう。例 党ば, $\mathrm{A}$ 成分と $\mathrm{B}$ 成分が鎖長で $1: 1$ であるような $\mathrm{ABA}$ 型共重合 体の場合， $t_{1}$ を最大緩和時間の $1 / 10$ とすると, B成分の $\chi_{2}$ 方向 の配向は完全に無視できる。これに対して，溶媒中に自由に浮か んだ鎖ではB成分の約 $20 \%$ は $\chi_{2}$ 方向に配向する. 分子量の十分 高い共重合体が得られれば, このよらな方法で分子運動を調べる ことは可能であろう.

上に述べたのは一つの思いつきである．からみ合った鎖の運動 に関して，液体論の現代的方法である散乱法がいずれは正しい答 えを見いだすであろう。しかしながら，現在の時点においては， も5少し正統的でなくても, 高分子濃厚系に適した方法を用いる ならば，あるいは分子運動の真の姿をとらえ，レオロジー理諭の 基礎を確立するための近道を見いだすことがでさるかも知れない， レオロジー研究の一半の努力は, このような方向に用いられても よいのではなかろらか.

本論文をまとめるに当たっては, 倉田道夫教授の御教示に負 ところが大きい，ここに謝意を表したい，本研究の一部は，文部
省科学研究費補助金（課題番号 57470072）によって行われた.

\section{文献}

1) Doi, M., and S.F. Edwards, J. Chem. Soc. Faraday Trans. II, 74, 1789, 1802, 1818 (1978); 75, 38 (1979).

2) Ferry, J.D., "Viscoelastic Proproperties of Polymers", 3rd ed., (1980), Wiley, New York.

3）升田利史郎, 日本レオロジー学会誌，12，7 (1984).

4) 山本三三三,「物体の変形学」, 誠文堂新光社 (1972).

5） A. S.ロッジ,「弾性液体」, 尾崎邦宏, 倉田道夫訳, 吉岡 書店 (1975).

6) Walters, K., "Rheometry", (1975), Chapman \& Hall, London.

7) Olabisi, O., and M.C. Williams, Trans. Soc. Rheology, 16, 727 (1972).

8) Higashitani, K., and A.S. Lodge, Trans. Soc. Rheology, 19, 307 (1975).

9) Philippoff, W., Trans. Soc. Rheology, 1, 95, 109 (1957).

10) Kotaka, T., M. Kurata, and M. Tamura, Rheol. Acta, 2, 179 (1962).

11）高橋雅與, 升田利史郎, 小野木重治, 日本レオロジー学会 誌, 5, 72 (1977).

12) Treloar, L.R.G., "The Physics of Rubber Elasticity", (1975), Clarendon Press, Oxford.

13) Janeschitz-Kriegl, H., Adv. Polym. Sci., 6, 170 (1969).

14) Janeschitz-Kriegl, H., "Polymer Melt Rheology and Flow Birefringence", (1983), Springer, Berlin.

15) Markovitz, H., and R.B. Williamson, Trans. Soc. Rheology, 1, 25, 37 (1957).

16) Coleman, B.D., and H. Markovitz, J. Appl. Phys., 35, 1 (1964).

17) Cox, W.P., and E.H. Merz, J. Polym. Sci., 28, 619 (1958).

18) de Gennes, P.G., J. Chem. Phys., 55, 572 (1971).

19）林静男,「レホロジー」, 講談社 (1973).

20）高橋雅興，小野木重治， 日本レオロジー学会誌， 2, 95 (1974)；3, 1 (1975).

21）尾崎邦宏, 日本レオロジー学会誌, 5, 163 (1977).

22) Meissner, J., J. Appl. Polym. Sci., 16, 2877 (1975).

23) Hansen, M., and F. Nazem, Trans. Soc. Rheol., 19, 21 (1975) ; 高橋雅興, 升田利央郎, 小野木重治, 日本レオ ロジー学会誌, 5, 72 (1977).

24) Crawley, R.L., and W.W. Graessley, Trans. Soc. Rheology, 21, 19 (1977).

25) Gortemaker, F.H., M.G. Hansen, B. de Cindio, H.M. Laun, and H. Janeschitz-Kriegl, Rheol. Acta, 15, 256 (1976) ; 16, 484 (1977).

26) Osaki, K., N. Bessho, T. Kojimoto, and M. Kurata, J. Rheol., 23, 457, 617 (1979).

27) Kimura, S., K. Osaki, and M. Kurata, J. Polym. Sci. Polym. Phys. Ed., 19, 151 (1981). 
28) Bird, R.B., R.C. Armstrong, and O. Hassager, "D ynamics of Polymeric Liquids", Vol. 1 (1977), Wiley, New York.

29）例えば, Meissner, J., T. Raible, and S.E. Stephenson, J. Rheology, 25, 1 (1981).

30）高橋雅興, 升田利实郎, 小野木重治, 日本レオロジー学会 誌, 11, 14 (1983).

31) Wagner, M.H., Rheol. Acta, 15, 133, 136 (1976).

32) Osaki, K., N. Bessho, T. Kojimoto, and M. Kurata, J. Rheology, 24, 125 (1980).

33) Fukuda, M., K. Osaki, and M. Kurata, J. Polym. Sci. Polym. Phys. Ed., 13, 1563 (1975).

34) Vrentas, C.M., and W.W. Graessley, J. Rheology, 26, 359 (1982).

35）福田三寿, 尾崎邦宏, 倉田道夫, 日本レオロジー学会誌, 2, 110 (1974).
36) Osaki, K., S. Kimura, and M. Kurata, J. Rheol., 25, 549 (1981).

37) Doi, M., J. Polym. Sci. Polym. Phys. Ed., 18, 2055 (1980).

38) Osaki, K., and M. Doi, Polymer Engineering Reviews, 4, 000 (1984).

39) Osaki, K., and M. Kurata, J. Polym. Sci. Polym. Phys. Ed., 20, 623 (1982).

40）土井正男, 日本レオロジ一学会誌, 12, (1984).

41）尾崎邦宏, 日本レオロジー学会誌, 9, 139 (1981).

42) Kurata, M., Macromolecules, 17, 000 (1984).

43) Doi, M., and N. Kuzuu, J. Polym. Sci. Polym. Let. Ed., 18, 775 (1980).

44) Richter, D., 私信.

45) Boué, F., M. Nierlich, G. Jannink, and R. Ball, J. Phys. (Paris), 43, 137 (1982). 